\title{
Embryomanipulation - eine Biotechnik für Tierzüchter
}

\author{
O.J. ROTTMANN
}

Lehrstuhl für Tierzucht der TU München

D-8050 Freising/Weihenstephan, B.R.D.

\begin{abstract}
Ähnlich der künstlichen Besamung und dem Embryotransfer, mit dem sie eng zusammenarbeitet, ist in der Mikromanipulation eine neue, wertvolle Biotechnik für den Tierzüchter zu sehen. Unter dem Gesichtspunkt der praktischen Durchführbarkeit der einzelnen Manipulationsmöglichkeiten befindet sich die Embryomanipulation noch am Anfang ihrer Entwicklung. Ihr wissenschaftlicher und ökonomischer Wert aber wird, wenn erst einmal praktikabel, beträchtlich sein. Als grundsätzlich möglich, jedoch mit bisher niederer. Erfolgsrate, werden verschiedene Einflußnahmen auf den Embryo und deren Ziele diskutiert : völlige Homozygotie einer Population, Vervielfältigung des gleichen Genotyps, Wirkung von Fremdgenen und-zellen in einem Organismus, Konservierung von Genotypen und Geschlechtsdiagnose.
\end{abstract}

\section{A problem of cattle selection for resistance to leukosis}

\author{
S.M. FYODOROVA, T.M. VILL', D.V. KARLIKOV \\ All-Union Research Institute of Farm Animal Breeding and Genetics, Leningrad, U.S.S.R.
}

This paper presents information on the influence of hereditary factors in leukosis etiology at pedigree cattle breeding farms of the Leningrad Region and the Latvian Soviet Socialist Republic. An effective sire evaluation for daughters' leukosis resistance and rational methods for selection and pair matings of animals not related to those with leukosis were suggested. Recommendations on dairy cattle selection for leukosis resistance were drawn up. The results obtained made it possible to use selection-genetic methods in prevention and control of cattle leukosis.

\section{Evaluation of the developmental capacity of cattle embryos after culture and deep-freezing}

\author{
E. SCHILLING, H. NIEMANN and D. SMIDT \\ Institut fïr Tierzucht und Tierverhalten (F.A.L.) Mariensee, 3057 Neustadt I, B.R.D.
}

The fluorescence dyes FDA and DAPI can be used for a rapid and very certain evaluation of the viability and developmental capacity of early embryonic stages. Viable embryos or blastomeres fluoresce brightly after FDA-incubation but they do not fluoresce after DAPI-incubation. In dead embryos or blastomeres the reactions are reversed with no fluorescence after FDA but positive fluorescence after DAPI. With both tests the evaluation of embryos by light microscopy can be improved by about $10 \mathrm{p}$. 100 to $20 \mathrm{p} .100$. Especially damages and degenerations of embryonic tissue by the freezing and thawing procedures will be recognized by the FDA- and DAPI-test. But more precise evaluation will be obtained with the DAPI-technique, because the dye penetrates the membranes immediately after the dead of the cells and labels the nuclei by a distinct fluorescence. Negative effects of manipulation procedures or other treatments of embryos can therefore rapidly and certainly diagnosed by the number and location of the non-viable cells. 